\title{
“O Negro André": a questão racial na vida e no pensamento do abolicionista André Rebouças
}

\author{
"O Negro André": the racial issue in the life and \\ work of the abolitionist André Rebouças
}

\begin{abstract}
Anita Maria Pequeno Soares ${ }^{a}$
Resumo O objetivo principal deste trabalho foi analisar como o contexto das relações raciais influenciou na construção de si e na produção intelectual do negro, intelectual e abolicionista André Rebouças. Por meio, sobretudo, de consultas a fontes de pesquisa primárias, tornou-se possível reconstituir o processo de construção de uma consciência de si, vivido por André Rebouças, enquanto negro, cuja ancestralidade remetia à África. Foi possível notar que algumas características do seu pensamento social radicalizam-se ao mesmo tempo em que se aprofunda o autorreconhecimento de sua condição racial, o que temporalmente situa-se no período em que se autoexilou do Brasil, imediatamente após a proclamação da República, em 1889. Durante sua vivência em África, rompeu definitivamente com o silêncio que, no geral, mantinha sobre a sua realidade racial. Nesse período, ocorre uma inflexão no que tange à construção de si, passando a enxergar-se e a reafirmar-se enquanto homem negro e africano. Esse momento foi interpretado, como bem sugeriu Mattos (2010), à luz do conceito de "dupla consciência", cunhado por Du Bois e aprofundando por Paul Gilroy em “O Atlântico Negro” (2012).
\end{abstract} Palavras-chave André Rebouças; Abolicionismo; Atlântico Negro.

Abstract The main objective of this work was to analyze how the context of racial relations influenced the construction of the self and the intellectual production of black intellectual and abolitionist André Rebouças. Through primary sources, it was possible to recreate the process of "self construction" lived by André Rebouças as a black man who had African ancestry. It was possible to notice that some characteristics of his social thought became radical at the same time the self-recognition of his racial condition became deeper, during the period in which he was self-exiled from Brazil, immediately after the proclamation of the republic in 1889. During his life in Africa, he broke his silence about his racial reality. In this period, the construction of his self

a Mestranda em Sociologia na Universidade Federal de Pernambuco. Graduada em Ciências Sociais (bacharelado) pela Universidade Federal de Pernambuco, com período sanduíche na Universität Hamburg - Alemanha onde obteve também a graduação em Sociologia. Atualmente, é integrante do Núcleo de Pesquisa de Relações Raciais - Frantz Fanon da UFPE. 
goes through a transformation, as he begins to see himself and to reaffirm himself as a black and African man. This awaken to "racial consciousness" was interpreted, like Mattos suggested (2010), inspired by the concept of "double consciousness", elaborated by Du Bois and further developed by Paul Gilroy in "The Black Atlantic" (2012).

Keywords André Rebouças; Abolitionism; Black Atlantic.

\section{INTRODUÇÃO}

André Pinto Rebouças foi um importante personagem da história do Brasil. Refinado intelectual, debruçou-se veementemente sobre a luta contra a escravidão. Sua proposta abolicionista diferia da de muitos outros, pois tinha o mérito de ser norteada por forte compromisso social. Isto é, ele não enxergava o fim da escravidão segundo um olhar estritamente econômico; suas propostas de reformas trazem questões sobre a estrutura fundiária do Brasil, herdada da colonização portuguesa, bem como remetem ao problema da extrema desigualdade social e racial que marcava a sociedade brasileira e que permanece atual. As ideias de Rebouças estavam repletas de um ideário de reforma agrária. Para ele, liberdade e propriedade de terra formavam um elo indissociável e fundamental para a integração dos ex-escravos à sociedade. A preocupação com a situação social dos antigos escravos reflete a responsabilidade social com a qual ele enxergava a problemática da abolição.

Amigo íntimo do imperador Pedro II, Rebouças fazia parte da elite intelectual brasileira no contexto do Segundo Reinado e, mesmo durante o período de autoexílio (1889-1898), continuou um intelectual assíduo, sempre fiel às suas propostas enquanto reformador social. A questão racial marcou a sua vida para além de sua defesa da abolição da escravatura. Isto é, foi de certo peculiar o fato de ter havido um homem negro de grande prestígio intelectual no contexto de escravidão e pós-escravidão. Por isso, o objetivo principal deste artigo é analisar como o contexto das relações raciais influenciou na construção de si e na produção intelectual do abolicionista André Rebouças.

Embora Rebouças tenha nos presenteado com um vastíssimo material autobiográfico, ele foi bastante cauteloso em fazer registros sobre a questão do racismo; postura que veio a ser alterada na última fase de sua existência. Após a proclamação da República, Rebouças optou por acompanhar a Família Real no exílio. Ficou claro, a partir da revisão bibliográfica e, principalmente, da leitura atenta de seus relatos durante sua vivência em África (1892-1893), que foi durante este período que ele quebrou a reserva com que costumava encarar a questão racial. Foi particularmente nesses escritos que ele expressou ser possuidor de uma identidade étnica e cultural pautada pela valorização de sua origem negra (MATTos, 
2013), sendo plausível pensar que o próprio exercício da escrita tenha contribuído para o amadurecimento desse processo de construção de sua identidade pessoal.

Durante o exílio, Rebouças cessou de escrever no diário - hábito que nutriu por anos - e passou a transcrever as cartas que emitia, reunindo-as no seu Registro de Correspondências, fonte de pesquisa fundamental para compreender as relações de tensão e de acomodação vividas cotidianamente por negros, mestiços livres e imigrantes na sociedade brasileira em contextos de escravidão e de pós-abolição, a partir de um caso particular: a trajetória de vida de André Pinto Rebouças.

A leitura das correspondências de Rebouças acarreta, também, maior compreensão acerca do intelectual que ele era, das suas propostas de reformas e, inclusive, sobre a dimensão da amizade íntima mantida com Pedro II. Além disso, foi possível refletir sobre a maneira através da qual lidou com o pensamento social brasileiro, que fazia uso de um discurso científico de cunho racista para responder ao “problema da nação", isto é, pensar a viabilidade da formação de uma "verdadeira" identidade nacional brasileira no contexto do pós-abolição.

Acredito na relevância de se estudar um homem negro de grande e rica produção intelectual no que tange ao contexto de uma sociedade racista como a brasileira. Como foi dito, André Rebouças foi um importante personagem da história do Brasil. Em contrapartida, muito pouco se escreveu sobre ele. Meu trabalho, então, também é importante por trazer à tona a vida e a obra desse intelectual de prestígio, cujo pensamento social destaca-se por sua singularidade.

A tarefa de pesquisar sobre a vida deste importante personagem da história do Brasil é facilitada graças à valiosa documentação histórica que existe sobre ele. A investigação sociológica a que me proponho baseia-se, fundamentalmente, na exploração de fontes primárias: a documentação textual manuscrita original existente no Arquivo André Rebouças, da Fundação Joaquim Nabuco (Recife-PE), mais especificamente o seu Registro de Correspondências, do volume um ao sete e o seu Diário pessoal. Faço, então, uso da biografia histórica de Rebouças como um método de análise sociológica, já que me proponho a analisar a sociedade na qual o personagem estava inscrito através de seus relatos autobiográficos. A sua trajetória de vida ilustra as tensões, conflitos e contradições de um tempo, todos essenciais para a compreensão do período. Neste caso, o próprio sujeito Rebouças encarna tais tensões.

\section{ANDRÉ REBOUÇAS - BREVE BIOGRAFIA}

No século XIX e no início do XX, a família de Rebouças representa umas das poucas famílias afro-brasileiras que conseguiram ascender socialmente e penetrar 
nas classes mais altas. Para conseguir tal feito, a trilha demarcada por critérios assimilacionistas foi essencial. Isto é, a alternativa adotada por muitos daqueles que foram colocados à margem da sociedade com base em critérios racistas foi a modificação dos traços culturais associados à vida que desejavam deixar para trás. Nessa época, a ideologia do embranquecimento foi o principal meio através do qual essa alternativa se viabilizou. Tratava-se do empenho, consciente ou inconsciente, em transformar "o negro em branco" através da miscigenação. Nessa lógica, os indivíduos de pele mais clara detinham maiores possibilidades de "escapar" à identificação social associada à escravidão e à subordinação. Não por acaso, era típico desses indivíduos uma tentativa de dissociação, parcial ou total, de suas “origens" (SpITZER, 2001).

A família de André Rebouças estava imersa nesse contexto e as possibilidades de ascensão galgadas por ela relacionam-se diretamente com a ideologia do embranquecimento e, consequentemente, com a tentativa de assimilação. Antonio, seu pai, era filho de uma mulher negra que havia sido escravizada, Rita Brasília dos Santos, e de um alfaiate português, Gaspar Pereira Rebouças. Quatro dos nove filhos de Rita e Gaspar casaram-se com cônjuges brancos e atingiram, em sua maioria, um alto grau de sucesso profissional - com exceção das mulheres, já que o machismo da época as privou da chance do estudo. Os homens, no entanto, tiveram acesso à educação formal em uma época em que estavam ocorrendo, no Brasil, a partir da chegada da corte portuguesa em 1808, uma reforma e uma reorientação educacionais significativas, particularmente nas áreas urbanas. Importante frisar que essa nova corrente de pensamento pedagógico em nada questionava os valores e ideias culturais dominantes a respeito das relações raciais (SPITZER, 2001).

Apesar de dois dos tios de André Rebouças terem se formado na Europa, um violonista e outro médico, foi seu pai, Antonio Pereira Rebouças, o caçula dos nove filhos, quem pareceu particularmente decidido a usar a instrução como trampolim para ascensão social. Autodidata, Antonio Rebouças foi um advogado sem diploma. Ele conseguiu que alguns advogados de destaque ficassem impressionados com os seus conhecimentos jurídicos e fizessem uma petição às autoridades do Rio de Janeiro para que lhe fosse concedida permissão para exercer a advocacia. Seu engajamento político também lhe rendeu o reconhecimento e a gratidão de alguns dos homens mais poderosos do país, como José Bonifácio e, até, o imperador Pedro I. Todo esse reconhecimento, no entanto, não mudou o fato de que ele viveu - e morreu - em uma sociedade escravocrata com uma longa tradição de preconceito racial. Em conversas com o filho André, ele discorreu sobre alguns episódios de racismo que sofreu, sugerindo que, de fato, o preconceito lhe deixara uma marca 
profunda. Apesar de ter sido a favor da abolição e de ter sentido na pele a dor da discriminação, durante toda a vida, evitou sistematicamente se identificar com os negros e, de modo geral, ligou-se a indivíduos das classes altas, o que reiterou seu sólido apoio à ordem estabelecida dominante (SPITZER, 2001).

Vindo à luz em plena Guerra da Sabinada (janeiro de 1838), André Rebouças nasceu em um contexto de grande efervescência histórica. Essa coincidência marcou a sua vida, já que, anos mais tarde, a mudança da sua família para o Rio de Janeiro se deu, também, como uma "fuga" dos remanescentes da rebelião. Seu pai, Antônio Pinto Rebouças, exercia a profissão de advogado e foi eleito deputado pelo Parlamento Imperial. Um ano após o seu nascimento, sua mãe, Carolina Pinto Rebouças, deu à luz ao seu irmão e companheiro fiel, Antônio Rebouças, também nascido na Bahia. Os irmãos, no entanto, foram criados no Rio de Janeiro. Em relação à educação dos filhos, coube ao pai assumir grande parte, ensinando-lhes as primeiras letras e utilizando livros preparados por ele próprio. Antonio Rebouças era um liberal, monarquista e abolicionista e, certamente, influenciou sobremaneira o filho André, que tinha grande admiração pelo pai (JuCÁ, 2001; TRINDADE, 2004).

Em 1846, a família migrou para o Rio de Janeiro. Lá os irmãos Rebouças formaram-se engenheiros militares pela Escola Militar - embrião da Escola Politécnica criada em 1874. Em 1861, partiram para a Europa em uma viagem de estudos financiada pelo pai; puderam, então, conhecer o que a engenharia do período podia proporcionar de mais moderno (TRINDADE, 2004). De volta ao Brasil, André Rebouças foi liberado da função de engenheiro militar - por ele exercida durante a Guerra do Paraguai - por questões de saúde. Dedicou-se, assim, ao cargo de professor da Escola Politécnica, como também às carreiras de engenheiro civil e empresário. Como grande reformador social, notabilizou-se na defesa da abolição da escravidão e na ênfase em projetos voltados para a modernização do país, entre os quais se incluía a democratização da propriedade fundiária. Amigo íntimo de Pedro II, decidiu-se por acompanhá-lo no exílio na Europa. Após a morte do Imperador, morou na África e, depois, em Funchal, na Ilha da Madeira, onde morreu em 1898.

A participação de Rebouças na Guerra do Paraguai (1864-1870) constitui-se certamente em um dos períodos de sua vida mais conhecidos, e a amizade com o imperador nasceu neste contexto. Ele chegou a se identificar - em carta que escreveu durante o exílio - como "um dos melhores amigos da família imperial”.

1 RebouçAs, André. Registro de Correspondência, Vol. II, 29 de junho de 1891. Acervo Fundação Joaquim Nabuco. 
Esse vínculo com Pedro II era baseado em grande admiração. A amizade e lealdade a Dom Pedro II, inclusive, foram um dos motivos que explicam sua súbita decisão de deixar o Brasil após a proclamação da República, em 1889, acompanhando o ex-imperador ao exílio.

Parece-me impossível pensar a vida e a obra de André Rebouças sem que haja questionamentos acerca da questão racial. À primeira vista, é difícil conceber a ideia de ter havido um refinado intelectual negro, engenheiro e amigo íntimo do imperador em uma sociedade branca, escravista e católica. Embora ele tenha sido enfático em sua defesa da abolição da escravatura, não há muitos relatos nos quais ele aborde a questão do racismo vivido cotidianamente.

Apesar de ter sido reticente sobre a questão do racismo na sua vida íntima, há relatos, no acervo de Rebouças, sobre episódios de discriminação vividos por ele. Episódios esses acontecidos no Brasil ou nos Estados Unidos. Ele os revela com um misto de desapontamento, tristeza e raiva. A frase "por causa de malditos preconceitos de cor" sempre está presente em seus diários, ao explicar as dificuldades ocasionais encontradas face à realização de algum empreendimento nos Estados Unidos (JUCÁ, 2001). É sabido que a sua vivência com o racismo contribuiu para aprofundar o progressivo interesse pelo abolicionismo e pelas questões sociais.

O racismo aflora com frequência em seus escritos pessoais como responsável por alguns insucessos profissionais. Ele cita, por exemplo,

[...] quando em dezembro de 1860, por malditos preconceitos de cor, negaram a mim e ao Antonio o prêmio de viagem à Europa e até o concurso aprovado pelo regulamento da escola redigido pelo liberal ministro J. Francisco Coelho, disse meu pai: "Minha Carolina (sua mãe), venderei os meus livros, mas os meninos hão de terminar sua educação na Europa" (JucÁ, 2001, p.42).

Além disso, "cumpre registrar que sempre que havia uma comissão gratuita e mefítica - matadouros e cemitérios - era para o 'negro André’”. ${ }^{2}$ Há, também, segundo pesquisas de Emília Viotti da Costa, no livro The Brazilian Empire, notícia de um episódio, citado com frequência, de uma dança concedida a Rebouças pela Princesa Isabel no Paço Imperial, como uma forma de expressar, em público, sua rejeição em relação ao preconceito e demonstrar a aceitação do amigo negro pela Família Real (JuCA, 2001, p.242). Ou quando da recusa grosseira e preconceituosa

2 RebouçAs, André. Registro de Correspondência, Vol. III, 29 de outubro de 1891. Acervo Fundação Joaquim Nabuco. 
de uma viscondessa a um convite de dança feita pelo jovem André, numa reunião social, ao que o conde d'Eu intercedeu oferecendo-lhe a esposa por companhia no bailado (Acioli, 2010).

Para além do contexto brasileiro, a estada de Rebouças nos Estados Unidos (1873) foi particularmente significante em relação à sua experiência com a questão do racismo, que se manifestou segundo o apartheid norte-americano. Em Nova Iorque, vários hotéis recusaram-lhe acomodação. Ele teve que se valer da intermediação do Consulado Brasileiro e da intervenção do coronel Henrique Ferreira de Aguiar, do ministro João Pedro de Carvalho Borges e do engenheiro José Américo dos Santos para ser aceito, finalmente, como hóspede do Washington Hotel, em um "quarto com saída imediata para a praça, com a condição de comer no quarto e nunca no restaurante". Ele registra essas dificuldades minuciosamente em seu diário: "[...] compreendi que era a dificuldade da cor a causa das recusas de aposentos". Em outras oportunidades, apenas por motivo de preconceito racial, Rebouças foi barrado na entrada da Grand Opera House, um dos seus programas preferidos, e em diversas outras ocasiões ele teve problemas em restaurantes (JUCÁ, 2001).

Apesar de ter sofrido na pele a experiência da segregação racial em sua visita aos Estados Unidos, Rebouças ficou encantado com o progresso técnico e o desenvolvimento econômico. Ele demonstrou muita familiaridade com a história, a literatura e o próprio estilo de vida do país, sobretudo com os aspectos da política e da legislação norte-americanas (MATTos, 2013). Embora expressasse o seu desdém pelo fato de os Estados Unidos serem uma república, admirava muito a legislação concernente à questão da posse da terra - particularmente o Homestead Act, de 1862 - que o influenciou, mais tarde, em sua luta em favor da reforma agrária (JUCÁ, 2001).

Durante o seu exílio em África, no entanto, Rebouças deixa de ser reticente em relação a esse assunto. Em tal período, ocorre uma mudança no que tange à construção da sua identidade racial. A referência a uma ancestralidade africana e o reconhecimento de si enquanto homem negro são recorrentes em seus escritos no exílio - na forma de cartas, já que, após sair do Brasil, ele perde o hábito de escrever em seu diário e passa a transcrever e a reunir, em seus Registro de Correspondências, todas as cartas que emitia. Sabe-se que a decisão de viagem à África está diretamente relacionada com o contexto de pós-abolição no Brasil e marca uma profunda inflexão na construção de si, sobretudo no que diz respeito à sua identidade racial (MATTOS, 2013). 
O Diário era uma obrigação que Rebouças tomou para si, não o esquecendo de anotar nem aos domingos e feriados. Só deixou de visitar suas páginas algumas vezes, quando doente. Todos os dias são assinalados cronometricamente, até os quartos de minutos. Registrava, também, com precisão, dia e noite, as mudanças meteorológicas do tempo (Acioli, 2010). Como já foi dito, durante o exílio autoimposto, André Rebouças cessou de escrever o Diário, mas passou a fazer cópias das cartas que enviava. Ele colecionou-as metodicamente, transcrevendo-as em cadernos, a que ele chamou Registro de Correspondências.

Os escritos de Rebouças fornecem pouca informação sobre a sua pessoa; sua vida emocional constitui um enigma. Há, porém, evidências de que ele era um homem solitário. Nunca se casou ou, aparentemente, ligou-se a alguém. Na verdade, seus escritos - sobretudo os do tempo do exílio - sugerem, claramente, que Rebouças foi uma pessoa introvertida, com forte tendência à melancolia (JUCÁ, 2001).

\section{PENSANDO 0 BRASIL}

\section{ABOLICIONISTA E REFORMADOR SOCIAL}

Na época de Rebouças, a escravidão era o pilar da hierarquia social e do estilo de vida do estamento dominante, estava na "corrente sanguínea nacional". Era também o alicerce do sistema político, porque eleitos e eleitorado eram majoritariamente os proprietários de escravos. Isto é, as bases estruturantes do Estado-nação eram escravistas, o que retardou a conversão do tema em problema na agenda pública. Daí sua legitimidade tácita, socialmente natural. A conjuntura internacional, no entanto, foi um dos grandes impulsores do movimento abolicionista brasileiro. A pressão externa reiterava que esse modelo estava sendo superado ao redor do mundo e o Brasil estava quase isolado em descompasso com os demais países (Alonso, 2015).

O escravismo brasileiro não teve mais sossego. Nova onda abolicionista internacional devastou seus congêneres Colômbia (1851), no Havaí (1852), na Argentina (1853), na Jamaica e na Venezuela (1854), no Peru e na Moldávia (1855), e a servidão acabou na Índia (1860) e na Rússia (1861). Em 1863, o processo chegou às colônias bávaras e chegaria de vez às portuguesas em 1869. No fim dos anos 1860, o Brasil estava escravista em companhia apenas de nações com as quais fugia de se ombrear: Zanzibar e Madagascar, Gana, Bulgária e o Império 
Otomano, que respectivamente carregaram o andor escravista até 1876,1878 , 1879 e 1882 (Alonso, 2015, p. 30).

André Rebouças foi uma das grandes figuras do movimento abolicionista brasileiro e, além disso, foi também um dos pouquíssimos que anteviram as implicações mais profundas da eliminação da mão-de-obra escrava no Brasil e sua substituição pela força de trabalho livre assalariada. Sabe-se, inclusive, que foi também autor da primeira versão da lei que, em 1888, constituiu a base do anteprojeto da Lei Áurea. A sua concepção de abolição era nutrida por uma ideia reformista, verdadeiramente preocupado com as ramificações e consequências advindas para os negros após o advento da liberdade (JuCÁ, 2001). Empenhado nessa luta, sua tática política foi utilizar os meandros das instituições. Ele transferiu para a política seu modus operandi de empresário, o lobby. A experiência com obras viárias lhe ensinara que deliberações cruciais dependem do núcleo do governo, que deve ser pressionado. Articulou-se, então, em extensa rede de relações interpessoais, tão crucial na sociedade de corte, e construiu pontes entre o associativismo abolicionista e o governo. Em junho de 1870, ele sintonizou vida privada e pública e libertou Roque, Júlia e Emília, os três últimos escravos de sua casa (Alonso, 2015).

Na historiografia brasileira, há uma tendência a ignorar a existência, entre o grupo de abolicionistas-reformadores, de um ideário de reforma agrária, cujo protagonista mais explícito foi Rebouças. Levanto, inclusive, a hipótese de que, devido à sua origem negra, ele tenha sido relegado a um plano secundário ou considerado irrelevante como pensador social, não apenas por seus contemporâneos, mas pela própria história. Além disso, sua participação efetiva na campanha abolicionista foi provavelmente obscurecida por causa de seu temperamento retraído e sua opção de ficar nos "bastidores" da política. Em contraste à pouca ênfase dada a Rebouças, Joaquim Nabuco disse:

[...] da Abolição ele foi o maior, não pela ação exterior, ou influência direta sobre o movimento, mas pela força e altura da projeção cerebral, pela rotação vertiginosa de ideias e sensações em torno do eixo consumidor e cadente, que era para ele o sofrimento do escravo (JUCÁ, 2001, p.69).

Enquanto reformador social, Rebouças também voltou a sua atenção para a questão da reforma agrária, ou seja, para as propostas de eliminação do sistema vigente de propriedade da terra, associado à instituição escravidão. Para ele, a resposta à multiplicidade dos problemas sociais no Brasil repousava, então, 
na correta organização da agricultura, e nesse contexto estaria a chave para o sucesso da integração dos negros após a emancipação: torná-los proprietários de parcelas de terra. O seu livro Agricultura Nacional apresenta a síntese efetiva do seu pensamento. Os principais argumentos sobre a questão agrícola estão fundamentados em propostas de reforma, nucleadas em torno da ideia daquilo que ele chamou de Democracia Rural Brasileira. O cerne de tal pensamento - o obstáculo representado pelo monopólio da terra à construção de um capitalismo dinâmico e de uma democracia genuína - mostra, também, a sua atualidade, já que essa é uma questão que ainda desafia pensadores e militantes (CosTA, 1999; JucÁ, 2001). A concepção de Democracia Rural é, frequentemente, atribuída a Joaquim Nabuco. Joselice Jucá (2001), no entanto, reitera que a precedência de Rebouças nos termos desse conceito é irrefutável.

Forjada sobre um ideal de reforma, a proposta abolicionista de Rebouças trata de erradicar a escravidão e o baixo assalariamento, permitindo ao liberto a alternativa de produzir para o mercado e de vender a sua força de trabalho. A concepção de "democratização do solo" é, também, um conceito basilar de sua teoria reformadora. Ao visualizar a reforma agrária como necessária à solução do problema da concentração da terra, Rebouças defendia, consequentemente, o acesso à propriedade da terra não só para os antigos escravos, mas também para os imigrantes europeus que chegaram ao Brasil após a Abolição.

É nesse sentido que Jucá traz sua frase, "quem possui a terra possui o homem", mostrando não apenas o significado mais profundo de sua concepção de escravidão, mas também a atualidade do seu pensamento social no Brasil. O cerne do pensamento de Rebouças era o de que a distribuição desigual de terra acarreta sérios problemas sociais, cuja maior consequência seria a escravização do camponês ao total controle do proprietário da terra. Rebouças acreditava resolutamente na viabilidade das suas reformas no contexto do Segundo Império - sem atentar para o fato de que a Monarquia se alicerçava sobre o poder político dos proprietários de terra (JuCÁ, 2001).

\section{DISCURSO CIENTÍFICO E PENSAMENTO SOCIAL NO BRASIL (1870 - 1930)}

Com base, sobretudo, nas reflexões do período do autoexílio, neste tópico irei refletir sobre de que maneira o elaborado pensamento de André Rebouças lidou com o discurso científico que era produzido no Brasil em finais do século dezenove.

3 Carta de André Rebouças a Joaquim Nabuco, de 03 de outubro de 1890. Acervo Fundação Joaquim Nabuco. 
Sendo o cerne deste trabalho pensar sobre a influência da questão racial na vida e no pensamento de um refinado intelectual negro em um contexto escravista e de pós-escravidão, cabe pensar que Rebouças viveu no seio de uma elite intelectual que propunha teorias racistas no que tange ao "problema da nação". Isto é, a viabilidade da formação de uma "verdadeira" identidade nacional em um momento em que aborígenes, africanos e mestiços eram compreendidos como obstáculos para que o país atingisse “o esplendor da civilização”. Sabe-se que ele viveu imerso nesse contexto de tal forma que, por exemplo, fazia parte, da Sociedade de Imigração para a qual a questão do "branqueamento da raça" era central (CosTA, 1999).

O século XIX ficou conhecido como a "era dos nacionalismos" (ANDERSON apud SchwARCZ, 2015, p.283). No Brasil, esse aspecto se evidencia, por exemplo, na tentativa de criação de heróis nacionais, povos originais, eleição de representações oficiais, etc. (Schwarcz; Starling, 2015). Em tal contexto, o "problema da nação" levou muitos intelectuais brasileiros - dentre eles, André Rebouças - a pensar a viabilidade de uma nação diante das nossas características, sobretudo em relação à situação dos negros. Era possível perceber nas entrelinhas das diversas narrativas sobre a nação como se articulavam as relações com a diferença e, de certa maneira, com a exclusão e a desigualdade.

Benedict Anderson (2008) afirma que o nacionalismo exerce grande influência no mundo moderno e nos alerta para o fato de que tanto a nacionalidade quanto o nacionalismo são produtos culturais específicos. Para Anderson (2008), a nação é uma comunidade política imaginada - e imaginada como sendo intrinsecamente limitada e, ao mesmo tempo, soberana. Ela é imaginada porque os seus membros jamais conhecerão, encontrarão, ou sequer ouvirão falar da maioria de seus companheiros, mas todos têm em mente a imagem viva da comunhão entre eles; e é limitada, porque mesmo a maior delas possui fronteiras finitas para além das quais existem outras nações. Além disso, a nação é uma comunidade imaginada porque, independentemente da desigualdade e da exploração efetivas que possam existir dentro dela, sempre é concebida como uma profunda camaradagem horizontal; é, inclusive, devido a essa falsa fraternidade que, nestes dois últimos séculos, tantos milhões de pessoas tenham morrido por essas criações imaginárias limitadas (ANDERSON, 2008).

A pretensão de Benedict Anderson é o entendimento do nacionalismo alinhando-o não a ideologias políticas conscientemente adotadas, mas aos grandes sistemas culturais que o originaram para reiterar o seu caráter ficcional. Com base nisso, o autor pôde perceber as bases sociais e historicizar o surgimento das comunidades imaginadas. A nação, logo, é desvinculada de quaisquer noções 
essencializantes. A importância de seu conceito para o propósito de estudar o Brasil é que, através dele, podemos enxergar a nação como uma construção. No âmbito dessa construção, havia um campo de disputas, porque projetos diversos entravam em conflito para pensar o país. No caso do Brasil, sabe-se que o resultado foi um projeto excludente que via a imigração europeia como mais vantajosa, porque oferecia o que os escravos e ex-escravos jamais poderiam oferecer: o branqueamento.

Segundo Schwarcz (1993), em finais do século dezenove, ao lado de um discurso liberal, tomava força, no Brasil, um modelo racial de análise em resposta à hibridação das raças - a qual era tida, naquele contexto, como um grande "tumulto". As teorias raciais chegam tardiamente ao Brasil, recebendo, em contrapartida, uma entusiasta acolhida, principalmente nos diversos estabelecimentos científicos de ensino e pesquisa, onde estava localizada grande parte da elite pensante nacional.

Diante do enfraquecimento da escravidão, que resultou em seu fim, e da necessidade de realização de um novo projeto político para forjar uma identidade para o país, os modelos raciais de análise tornaram-se um caminho teórico viável para justificar o status quo da época. Houve, para tal propósito, um esforço de adaptação que atualizou o que combinava e descartou o que de certa forma era problemático para a construção de um argumento racial no país. Embora hoje seja bastante renegado, esse foi um momento na história intelectual do Brasil no qual pressupostos racistas foram abertamente postulados (ScHWARCZ, 1993).

De acordo com tais modelos de análise, era a partir da ciência que se reconheciam diferenças e se determinavam inferioridades raciais. Assim, teorias como o evolucionismo social, o positivismo, o naturalismo e o social darwinismo começaram a se difundir, no Brasil, a partir dos anos 1870. Dom Pedro II, em tal época, foi denominado "mecenas da sciencia", e a amizade que tinha com Rebouças só reitera o quanto este último viveu mergulhado em um contexto no qual o racismo era legitimado cientificamente (SchWARCZ, 1993). Um exemplo são as visitas de André ao Palácio de Petrópolis, nas quais discutiam sobre, dentre outros, Charles Darwin e a Nova Biologia (JuCÁ, 2001).

Esses modelos europeus de análise - muito embora já bastante ultrapassados na Europa - serviam também ao propósito de diferenciar o Brasil das demais repúblicas latino-americanas e de aproximá-lo dos modelos europeus de conhecimento e civilidade (SchWARcz, 1993). Essa preocupação também perpassava o pensamento de Rebouças, a exemplo de quando ele escreveu, sobre a situação do 
Brasil pós-abolição, que a República estava “empurrando nossa mísera pátria para o lamaçal em que se debatem horrendamente o Chile e a Argentina4".

Como consequência desse ideário cientificista, houve, também, no Brasil, a adoção de grandes programas governamentais de higienização e saneamento. $\mathrm{O}$ propósito era trazer uma nova racionalidade científica para os abarrotados centros urbanos, implementar projetos de cunho eugênico que pretendiam eliminar a doença, separar loucura e pobreza. O ápice dessa política de higienização se deu com a "Revolta da Vacina" (1904). Nos escritos de Rebouças, a temática da higiene também era recorrente e ele defendia, por exemplo, o ensino obrigatório da higiene desde o escolar primário ${ }^{5}$.

A visão monogenista, dominante até meados do século XIX na Europa, acreditava que a humanidade era una, mas que havia um "gradiente" que a localizava segundo graus que iam do mais perfeito ao menos perfeito. Isto é, a evolução era o paradigma. Essa visão fez parte do pensamento intelectual forjado em modelos racistas no Brasil de finais do século dezenove (ScHWARCZ, 1993) e foi partilhada por Rebouças em alguns aspectos. O seu artigo O problema da África está recheado de citações cunhadas em uma perspectiva monogenista da questão racial - por exemplo, ao acreditar que o Brasil deveria sanar a dívida com a África, civilizando-a. Em outro artigo escrito em Lisboa, intitulado O problema Hebreu ${ }^{6}$, também publicado na Revista de Engenharia, utiliza a noção de raça como sinônimo de nação e de cultura, ao mesmo tempo em que se refere à raça humana "a que todos os povos pertenciam, ainda que com suas especificidades socioculturais e em diferentes estágios de civilização" (REBouçAs apud MATtos, 2013, p.6).

Embora também considerasse a imigração dos chineses uma forma de escravidão, Rebouças colocava-se contra essa imigração também por outros motivos. Acreditava que os asiáticos tinham uma civilização corrompida e que, por isso, eram indesejáveis para o Brasil; diferente dos africanos a quem considerava possível civilizar. Nas suas próprias palavras:

O africano é simplesmente um homem por civilizar; mas o Chin, o proletário asiático, é um ente corrupto e depravado, durante milhares de anos, pela escravidão, pela embriaguez, pelo ópio e pela ferocidade Oriental; é um ser incivili-

4 Rebouças, André. Registro de Correspondência, Vol. II, 22 de maio de 1891. Acervo Fundação Joaquim Nabuco.

5 Rebouças, André. Registro de Correspondência, Vol. IV, o8 de novembro de 1891. Acervo Fundação Joaquim Nabuco.

6 ReBouças, André. O problema Hebreu, Revista de Engenharia, p. 258-26o, 28 de maio a 28 de junho de 1891. 
zável. Resistente e refratário a todo o progresso, corrompendo a sociedade que o admite em seu seio, em lugar de aperfeiçoar-se ${ }^{7}$.

O preconceito de Rebouças em relação aos chineses também é reflexo do pensamento social da sua época. Os chineses eram entendidos como "inassimiláveis, portadores de línguas e costumes estranhos aos nossos, praticantes do suicídio e do ópio” (Nogueira apud Schwarcz, 2011, p.184). Por conta dessa visão estereotipada, os imigrantes orientais contavam com graves entraves à sua entrada no Brasil.

A finalidade da apropriação desse discurso científico no país foi a de negar a civilização aos negros e mestiços e garantir que o futuro do Brasil seria "branco e ocidental" (SchwARCZ, 1993). Embora seja possível, através da leitura de seus escritos, enxergar que Rebouças foi "um homem de seu tempo", reiterando alguns pensamentos da época, é sabido também que ele era, antes de tudo, um abolicionista e reformador, cuja proposta de reforma social ia de encontro à manutenção do status quo que embasava os discursos raciais no Brasil; era também um intelectual negro que viveu no meio de uma elite racista de cujos discursos ele mesmo era vítima e, em contraponto a tais discursos, Rebouças passou a se afirmar enquanto homem negro, africano.

\section{"O NEGRO ANDRÉ"}

\section{REFLEXÕES NO AUTOEXÍLIO}

No seio da família Rebouças, André nasceu na segunda geração de tentativa assimilacionista. Pode-se afirmar que sua trajetória foi de muito sucesso e prestígio enquanto engenheiro, empresário e abolicionista. Por quase toda a vida, ele se identificou inteiramente com o mundo do grupo dominante. O processo de assimilação, no entanto, não assegurou a continuidade de sua aceitação e de sua segurança no mundo dos dominadores. Quando finalmente se percebeu rejeitado e excluído pelo racismo, a solidez de sua confiança no pertencimento ao grupo hegemônico e a profundidade de seu compromisso com ele foram questionados. O momento do exílio o levou à completa desilusão e à conscientização de sua posição marginalizada entre dois mundos. Uma perturbadora crise de identidade foi inevitável (SPITZER, 2001).

7 Rebouças, André. Registro de Correspondência, Vol. VI, 23 de julho de 1893. Acervo Fundação Joaquim Nabuco. 
O dia 16 de novembro de 1889 foi um dos mais importantes na vida de Rebouças: o último de sua vida passado no Brasil, devido à sua súbita decisão de deixar o país. A ida para o exílio se deu em companhia ao amigo, o Imperador Dom Pedro II, quando de sua retirada para Portugal; inclusive, seus relatos, a partir de então - imediatamente após o advento da República - descrevem a vida íntima do imperador nesse momento tão crucial (Acioli, 2010). Os seus últimos anos de vida e as cartas por ele escritas no exílio são marcados, também, por profunda depressão. A maneira como se deu a abolição da escravatura - sem qualquer reforma social - e a proclamação da República foram de encontro aos ideais propostos por Rebouças.

Em carta a Nabuco, manda um recado: "diga ao Brasil inteiro: cuidem dos negros libertos, que acumularam, durante 03 séculos de trabalho a chicote, as riquezas que estão hoje esbanjando ${ }^{8}$ ". Na verdade, no que tange ao fim da escravidão, em termos de ganhos sociais e econômicos, os antigos escravos permaneceram marginalizados dentro da sociedade. Isto é, a Abolição pode ser considerada como uma significativa mudança econômica, mas não foi capaz de operar uma real e profunda transformação segundo os moldes de uma reforma social mais abrangente. Permaneciam, assim, no papel, as ideias de implantação da reforma agrária preconizadas no regime monárquico e estimuladas por Pedro II. Consequentemente, Rebouças entristeceu e fortaleceu o nível de suas críticas contra o novo regime no Brasil (JUCÁ, 2001).

Após a leitura de sete volumes do Registro de Correspondência, de Rebouças (de 1891 a 1893), não há dúvida acerca da depressão que o acompanhou em seus últimos anos de vida. Associada à tristeza com a qual viveu os seus anos longe do Brasil, ele expressa uma aguda consciência de suas origens africanas. Na realidade, a decisão de viagem à África marca uma profunda inflexão na construção de si e, nas correspondências escritas nessa fase, de forma contundente, quebrou o silêncio sobre sua identidade racial, até então predominante em sua vida pública e na narrativa de si registrada em seu diário (MATTos, 2013).

Em outubro de 1891, ainda em Cannes, André Rebouças, pela primeira vez, referiu a si mesmo como "o Negro Andrée" e essa referência, a partir de então, tornou-se constante nas suas correspondências. Essa mudança que o acometeu no contexto do exílio se expressa, por exemplo, nos momentos em que, através de

8 Rebouças, André. Registro de Correspondência, Vol. II, 17 de junho de 1891. Acervo Fundação Joaquim Nabuco.

9 RebouçAs, André. Registro de Correspondência, Vol. IV, 29 de janeiro de 1891. Acervo Fundação Joaquim Nabuco. 
suas cartas, assumiu sua "alma africana" para todos os correspondentes. Ainda em Cannes, declarou-se "meio brasileiro meio africano, não podendo voltar ao Brasil, parece-me melhor viver e morrer na África ${ }^{10 ”}$. Em relação ao imperador D. Pedro II, que já se encontrava doente e por quem tinha sincera veneração, disse "o nosso velho imperador, que necessita da minha dedicação africana; bem africana" ${ }^{11 "}$.

Em resposta a Haupt e a Taunay — amigos que desaprovavam a sua ida à África - ele questiona: “como o africano André Rebouças há de recuar por medo do sol e da inclemência do continente de seus pré-avós?!12”. Através dessa referência a uma ancestralidade africana, acreditava ter pleno direito de projetar, em África, os sonhos frustrados em relação ao Brasil ${ }^{13}$.

Em 27 de março de 1892, Rebouças finalmente viajou para o continente africano, através do Canal de Suez, com destino a Lourenço Marques. Já em 26 de maio, estava na África do Sul, confiante na ação dos ingleses na repressão à escravidão e ao tráfico de escravos. "Na África Oriental ainda estão muito vivos os estigmas do hediondo escravagismo", escrevia, mas acreditava que "em South Africa, o negro já está evoluindo para a Democracia Rural; já tem casa, plantação... 14". Na África do Sul, fixou-se em Barbeton, a que chamou de "Petrópolis africana" em carta a Antonio Julio Machado ${ }^{15}$ (MatTos, 2013).

Em pouco tempo, porém, suas ilusões com a colonização inglesa na África do Sul se desvaneceriam. Rebouças foi surpreendido pelas práticas racistas dos boers e pelo retorno do fantasma do escravagismo. Em Capetown, ainda conseguiu regularizar a chegada dos recursos vindos de Portugal e do Brasil junto ao Bank of South Africa; sustentando, assim, na África do Sul, o que definia como uma "anti slavery and scientific mission”. No entanto, as práticas de discriminação racial, toleradas pelos ingleses, atingiram-lhe (MATtos, 2013).

A sua ilusão acerca da África do Sul se foi por terra, já que, segundo ele, os ingleses insistiam:

10 RebouçAs, André. Registro de Correspondência, Vol. IV, 12 de janeiro de 1892. Acervo Fundação Joaquim Nabuco.

11 RebouçAs, André. Registro de Correspondência, Vol. III. Acervo Fundação Joaquim Nabuco.

12 RebouçAs, André. Registro de Correspondência, Vol. IV, o3 de março de 1892. Acervo Fundação Joaquim Nabuco.

13 Rebouças, André. Registro de Correspondência, Vol. IV, 14 de maio de 1892.Acervo Fundação Joaquim Nabuco.

14 Rebouças, André. Registro de Correspondência, Vol. V, 14 de junho de 1892. Acervo Fundação Joaquim Nabuco.

15 Rebouças, André. Registro de Correspondência, Vol. IV, 28 de maio de 1892. Acervo Fundação Joaquim Nabuco. 
a) Em recusar propriedade territorial ao Africano - Que horror?! O africano não pode ser proprietário territorial no seu próprio continente africano!

b) Em recusar, ao africano, direitos eleitorais; em sujeita-lo a leis bárbaras; a julgá-los em tribunais ad-doc; usando e abusando da atroz pena de açoite.

c) Em dar curso à brutalidade yankee de recusar Negros e Mulatos nos hotéis e até fazer dificuldades em vender-lhe nas lojas de moda e perfumaria ${ }^{16}$.

Seu primeiro artigo sobre a África, O problema da África ${ }^{17}$, foi escrito ainda em Lisboa, em 07 de novembro de 1890. Nele buscava refletir sobre as relações entre escravidão e racismo (MATTOS, 2013):

\begin{abstract}
A África foi sempre o continente da escravidão... A cor preta foi sempre apreciada pelos exploradores de homens como uma justificativa de sua iniquidade. (...) A cor negra veio salvar essa dificuldade moral... Porque todo criminoso quer ter uma justificativa do seu crime.
\end{abstract}

Rebouças projetou muito dos seus ideais de reforma social do Brasil para África, o que reflete um ingênuo transplante do seu "sonho brasileiro" da América para África (JuCÁ, 2001). Por isso, sua luta em prol da abolição da miséria e da escravidão associada à democratização do solo se deu nos dois contextos. Dizia que

[...] ensinar o Negro Africano a agricultar: isso é o principal. Ler e escrever virão depois. É preciso que fique claro que só se pede para o Africano a mais elementar Justiça; equidade nos pagamentos de salários; e um pedaço de terra para permitir-lhe evoluir para a propriedade e para a família. Negar isso é maldade satânica ${ }^{18}$.

Imerso na tristeza que o acometeu no exílio, Rebouças não cessou de declarar a sua total abominação em relação à escravidão. Nas suas cartas, há alguns relatos sobre o quão cruel era o sistema escravocrata. Por exemplo, quando ele fala sobre:

a nudez em que sempre mantém o negro africano: o famigerado escravocrata Manoel Antonio de Souza fuzilava os africanos que encontrava vestidos de cal-

16 Rebouças, André. Registro de Correspondência, Vol. V, 23-27 de dezembro de 1892.Acervo Fundação Joaquim Nabuco.

17 Rebouças, André. O Problema da África. Revista de Engenharia, p. 249-251, 14 de janeiro a 14 de fevereiro de 1891.

18 Rebouças, André. Registro de Correspondência, Vol. IV, 28 de maio de 1892. Acervo Fundação Joaquim Nabuco. 
ças!!! O espírito satânico da escravidão tem horror ao negro vestido à europeia; quer o mísero nu ou seminu; envolvidos em trapos de algodão [...] para depois ter disso mesmo argumentos e pretextos para os sofismas da inferioridade de raça e de incapacidade de evoluir para a civilização igualitária ${ }^{19}$.

"Empenhado até a morte na campanha abolicionista [...] a odisseia do negro André não cabe em 24 contos ${ }^{20}$ ". Por isso, ele dedicou-se também a escrever contra a escravização dos imigrantes, a qual chamou de "escravidão branca". Esse ponto do seu pensamento - enquanto reformador social - opunha-se veementemente ao pensamento de Nabuco segundo o qual "o branco se vende e o negro é vendido".

No exílio (1889-1898), Rebouças permaneceu fiel às suas críticas contra o uso religioso associado à política escravocrata:

Não faltaram nem matadouros nem jesuítas com seus rosários e seus bentinhos... Desde 1535 que se mata e se reza no Rio da Prata. - Qual o resultado? [...] Uma corja de megalômanos; de jogadores da escravidão; da infâmia de ser o último povo cristão que explora e vive à custa do suor do Negro Africano ${ }^{22}$.

Tanto o contexto social brasileiro quanto o africano incitaram-no à luta política e inspiraram-no em relação a suas propostas de reformas; tais contextos, no entanto, acarretaram grande tristeza na alma de um homem tão comprometido com o social. Por isso, os últimos anos de sua vida são marcados por grande melancolia e as suas correspondências são um testemunho das suas desilusões. Em carta a Taunay ${ }^{23}$, ele diz:

Ah! Meu Taunay! É preciso que eu lave todas essas feridas do meu coração Africano nas águas do Nilo, do Níger, do Congo, do Zambeze e dos lagos equatoriais; e, se for necessário, no mediterrâneo e nos oceanos atlântico e índico.

19 Rebouças, André. Registro de Correspondência, Vol. IV, 27 de maio de 1892. Acervo Fundação Joaquim Nabuco.

20 Rebouças, André. Registro de Correspondência, Vol. III, 29 de outubro de 1891. Acervo Fundação Joaquim Nabuco.

21 Rebouças, André. Registro de Correspondência, Vol. II, 17 de junho de 1891. Acervo Fundação Joaquim Nabuco.

22 Rebouças, André. Registro de Correspondência, Vol. IV, o3 de dezembro de 1891. Acervo Fundação Joaquim Nabuco.

23 RebouçAs, André. Registro de Correspondência, Vol. IV, 02 de maio de 1892. Acervo Fundação Joaquim Nabuco. 
Associada à melancolia, por vezes havia espaço para esperança:

[...] mas já foi pior... Eu mesmo vi os míseros escravizados em máscaras de folhas de Flandres, e em ferro ao pescoço, carregando água e barris pelas ruas do Rio de Janeiro... Oh Sim! Já foi pior... Não há de desanimar... A questão é só tempo para o progresso. É assim tristemente filosofando que passo dias e noites...

Embora manifestasse a intenção de morrer em África, Rebouças decidiu partir para Funchal, na Ilha da Madeira, onde amigos portugueses tinham correspondentes (Matтos, 2013). Na sua última carta de Capetown a Taunay, descreveu sua partida como um "novo capítulo na Odisséia deste mísero Ulysses Africano²".

A vivência no exílio em África e a consequente inflexão na sua concepção de si enquanto negro e africano são de extrema relevância na trajetória de Rebouças porque, além de reiterar as suas propostas enquanto reformador social, elucidam sobre a questão racial que sempre perpassou a sua existência. No fim de um de seus artigos, Hebe Mattos (2013) lança a possibilidade de compreendermos a mudança na afirmação racial que o acometeu no exílio segundo o tipo de cultura política a que Paul Gilroy chamou de dupla consciência dos intelectuais negros do Ocidente. A partir da leitura atenta das fontes primárias deixadas por André Rebouças na sua época de exílio, aprofundo essa análise e associo o seu pensamento às narrativas do Atlântico Negro.

\section{A “DUPLA CONSCIÊNCIA” DE UM INTELECTUAL NEGRO NO OCIDENTE}

O caso de André Rebouças tem sua especificidade, já que, até hoje, é impossível afirmar categoricamente que o Brasil é parte do Ocidente. Para além do mérito dessa discussão, que permanece atual, acredito na viabilidade de pensá-lo segundo os moldes propostos por Gilroy, a partir dos quais o Ocidente não pode ser compreendido sem a dimensão do colonialismo. A dupla consciência dos intelectuais negros, então, acomete os pensadores negros do âmbito do Atlântico Negro, tanto que o próprio Gilroy (2012) reiterou que a história do Brasil sobre os seus contatos com a África também deveria ser acrescentada a tais narrativas, ou que até seja mais pertinente pensar na ideia de um "Atlântico sul negro".

A biografia de Rebouças reitera o quanto ele esteve imerso em um "ocidente expandido”. Aspectos como a sua formação cristã, parte de sua formação na Europa,

24 RebouçAs, André. Registro de Correspondência, Vol. V, 20 de junho de 1893. Acervo Fundação Joaquim Nabuco. 
a vida no seio da família real, etc., reforçam a ambivalência de ter sido um homem negro de grande prestígio intelectual em meio a uma sociedade escravista. Podemos pensar, também, no pensamento de Frantz Fanon, o qual nos traz importantes insights sobre as ambivalências da questão racial no mundo colonizado. Fanon, acredito, também esteve imerso em um contexto de "dupla consciência" entre a França, a Martinica e, até, a Argélia. O exemplo mais emblemático é o do sociólogo negro norte-americano Du Bois, a quem cabe, inclusive, o mérito de, a partir de sua própria vivência, ter cunhado o termo "dupla consciência".

Para associar a vida de André Rebouças à "dupla consciência” dos intelectuais negros do Ocidente, é preciso acrescentar os seus escritos às narrativas da história do "Atlântico Negro". Os textos produzidos no contexto do Atlântico Negro expressam da maneira poderosa uma tradição de escrita na qual a autobiografia se torna um ato ou processo de simultânea autocriação e autoemancipação (GILROY, 2012). O material autobiográfico deixado por André Rebouças compreende um período de vinte e três anos da sua vida e é possível perceber, através da sua escrita, um processo de construção de si. Esse processo de autocriação culmina com os seus escritos no exílio quando, enfim, Rebouças passa a se afirmar enquanto homem negro.

Expressão cultural da diáspora africana, o Atlântico Negro chama a nossa atenção ao mar e à vida marítima, que se movimenta e que cruza o oceano Atlântico, fazendo surgir culturas planetárias mais fluidas e menos fixas. Essa formação política e cultural moderna transcende tanto as estruturas do estado-nação como os limites da etnia e da particularidade nacional. Trata-se de identidades que estão sempre inacabadas, sempre sendo refeitas (GiLroy, 2012).

A sugestão de Gilroy é que se tome a contracultura do Atlântico Negro não simplesmente como mais um repertório de manifestações artísticas e culturais, dissociadas da política, mas como um discurso filosófico que reinterpreta a modernidade e reconta sua história, a partir da perspectiva de quem sempre esteve fora das narrativas nacionais com seus heróis brancos. O que há de singular e comum no âmbito do Atlântico Negro, para Gilroy, não é qualquer vínculo primordial ou biológico entre os membros da diáspora negra. Não é o corpo negro, em seu sentido físico, absoluto, que aproxima as vidas na diáspora, mas formas similares de tradução dos processos de exclusão e discriminação aos quais os possuidores de um corpo negro estiveram e estão submetidos nas sociedades modernas: "O fenótipo não tem qualquer sentido natural anterior a seus códigos 
culturais e historicamente mutáveis. O processo de significação é a única questão que importa” (Gilroy apud Costa, 2006, p.119).

Ao repensar a modernidade por meio da história do Atlântico Negro e da diáspora africana no hemisfério ocidental, Gilroy buscava tornar "os negros percebidos como agentes, como pessoas com capacidades cognitivas e mesmo com uma história intelectual - atributos negados pelo racismo moderno" (GILroy, 2012, p. 40). O seu argumento se desenvolveu no sentido de mostrar que há outras bases para a ética e a estética além das que parecem imanentes às versões de modernidade elaboradas pelas "míopes teorias eurocêntricas".

Tanto os defensores como os críticos da modernidade parecem não atentar para o fato de que a história e a cultura expressivas da diáspora africana, a prática da escravidão racial ou as narrativas de conquista imperial europeia fazem parte da modernidade e, mais além, a escravidão foi uma de suas premissas. Isto é, a universalidade e a racionalidade da Europa e da América Iluministas foram usadas mais para sustentar e transplantar, do que para erradicar uma ordem de diferença racial. Diante disso, não é surpreendente que, se a história da escravidão chega a ser percebida como relevante, ainda assim é considerada uma tarefa para autores negros. Ela se torna nossa propriedade específica, em lugar de uma parte da herança ética e intelectual do Ocidente como um todo, e seus reflexos são sentidos até hoje (Gilroy, 2012). Segundo Costa (2006), o Atlântico Negro corresponde a uma dimensão esquecida da modernidade e a escravidão uma filha bastarda que a história moderna sempre procurou esconder.

Como Douglass, Du Bois quis estabelecer que a história dos negros no Novo Mundo, particularmente as experiências do tráfico escravo e da plantation, eram uma parte legítima da história moral do Ocidente como um todo. Não eram eventos únicos - episódios discretos na história de uma minoria - que poderiam ser apreendidos por seu impacto exclusivo sobre os negros em si mesmos, nem eram aberrações em relação ao espírito da cultura moderna que provavelmente teriam de ser superados pelo progresso inexorável rumo a uma utopia secular, racional. A existência permanente do racismo desmentiu estes dois veredictos e exige que consideremos mais profundamente a relação de terror e subordinação racial com a própria natureza interna da modernidade (GILROY, 2012, p. 154).

A história do Atlântico Negro baseia-se, sobretudo, no movimento e no deslocamento, próprios da diáspora. Essa maneira de enxergar aparece como uma 
alternativa à metafísica da "raça", da nação e de uma cultura territorial fechada, codificada no corpo; trata-se de um conceito que ativamente perturba a mecânica cultural e histórica do pertencimento (GiLroy, 2012). Fica claro, então, que Gilroy é crítico ao afro-centrismo e busca mostrar que as manifestações culturais no âmbito do Atlântico Negro são sempre recombinações e reinvenções, articulações, cujo sentido político não precisa ter sua fidelidade mensurada em relação às "origens comuns".

A história da diáspora africana se desenvolve fora da órbita da política formal, se valendo fundamentalmente da performance, da dança e da música como forma de sua constituição, e sua reconstrução vai além de estender e aprofundar os direitos e possibilidades de participação dos descendentes de escravos no marco da história moderna; coloca em discussão o próprio processo de construção da política moderna enquanto espaço privilegiado de representação dos interesses e das visões de mundo do "homem-branco-europeu" (CosTA, 2006).

A propensão não nacional da diáspora é ampliada quando o conceito é anexado em relatos antiessencialistas da formação de identidade como um processo histórico e político, e utilizado para conseguir um afastamento em relação à ideia de identidades primordiais que se estabelecem supostamente tanto pela cultura como pela natureza. Ao aderir à diáspora, a identidade pode ser, ao invés disso, levada à contingência, à indeterminação e ao conflito (GILrOY, 2012, p. 19).

Pensar André Rebouças como um intelectual do Atlântico Negro é coerente, sobretudo, devido à etapa da sua vida no exílio em África. Como já foi dito, esse momento representou uma grande mudança em relação à sua construção de si, já que ele passou a se afirmar como "o negro André". Tendo vivido uma trajetória marcada pela ambivalência de ser um refinado intelectual em uma sociedade escravista, Rebouças passou muito tempo sendo reticente em relação ao racismo. No âmbito do deslocamento próprio das culturas diaspóricas do Atlântico Negro, ele chegou à África, e esse movimento conduziu a construção da sua identidade ao conflito. Por isso, Hebe Mattos (2010) lança a possibilidade de interpretarmos a narrativa do "negro André" como reflexo da dupla consciência de um intelectual negro no Ocidente.

Esforçar-se para ter, ao mesmo tempo, duas identidades requer algumas formas específicas de "dupla consciência", conceito que Gilroy buscou em Du Bois. Essa duplicidade - ser interno e ao mesmo tempo externo ao Ocidente - muitas vezes se afirma como a força constitutiva da experiência negra no mundo moderno. 
Na obra de Du Bois The Souls of Black Folk, a dupla consciência, como a experiência basilar dos negros no Ocidente, é em si expressa no duplo valor de canções que sempre são, simultaneamente, americanas e negras (esse aspecto é caro a Gilroy, porque a música, para ele, é uma dimensão fundamental do Atlântico Negro). A própria vida de Du Bois, seu status eminente como primeiro sociólogo negro e pioneiro da disciplina na América, oferece outra importante razão para utilizar sua vida e obra no enfoque da "dupla consciência”, já que a sua sociologia também traz a marca de sua ambivalência (GILROY, 2012).

Existe uma série de razões para utilizar a vida e os escritos de Du Bois como meio para desenvolver minha discussão sobre a modernidade e para elaborar um relato intercultural e antietnocêntrico da história e da cultura política negra moderna. Ele também era um negro americano, mas, ao contrário de Richard Wright, que é o objeto central do próximo capítulo, foi criado em uma minúscula comunidade negra da Nova Inglaterra, Great Barrington, Massachusetts. Comparado com o Sul, onde Du Bois iria descobrir e internalizar um novo sentido de ser negro, seu local de nascimento em uma cidade do norte foi visto por alguns comentadores de sua vida como inautêntico e não suficientemente negro por causa de sua distância da instituição da escravidão. Os problemas da ontologia e da identidade racializadas - a tensão entre ser negro e tornar-se negro - estão, portanto, profundamente gravados na própria vida de Du Bois (GILROY, 2012. p. 230).

A tensão entre ser negro e tornar-se negro é notória também na vida de Rebouças. Certamente, o tornar-se negro tardou um pouco a acometê-lo devido à dificuldade em afirmar uma identidade marginalizada, refém de todo um ideário racista. O próprio Du Bois afirmou que "é uma sensação peculiar, esta dupla consciência, este sentido de sempre olhar para o próprio eu por meio dos olhos dos outros, de medir a própria alma pela fita métrica de um mundo que o olha com divertido desdém e pena" (apud Gilroy, 2012, p. 263).

Du Bois também foi interessante para o propósito de Gilroy por conta de sua falta de raízes e da proliferação de rotas em sua vida nômade. Ele viajou muito e sua vida se encerrou no exílio africano, após ter fixado residência em Gana e renunciado à cidadania americana aos 95 anos de idade. Rebouças também manifestava vontade de morrer em África, contudo o fim de sua vida se deu de forma trágica (suicídio) na Ilha da Madeira. O conceito de dupla consciência foi produzido não só para expressar o ponto de vista distintivo dos negros americanos (Du Bois, que 
cunhou o termo, era americano), mas também para esclarecer a experiência das populações pós-escravas em geral. Através de tal conceito, Gilroy pôde interpretar as culturas dos negros da diáspora como expressões das ambivalências geradas pela modernidade e seus posicionamentos dentro dela.

As narrativas do Atlântico Negro não devem ser identificadas exclusivamente com o projeto de construção nacional, pois a lógica do grande movimento político no qual esses textos se situam e para o qual contribuem opera em outros níveis, que vão além das fronteiras nacionais. Esses textos - e aí incluo a obra de Rebouças - pertencem também à rede de identidades e interesses da diáspora africana, rotulada por Gilroy como Atlântico Negro (GiLroy, 2012).

\section{CONCLUSÃO}

Importante personagem da história do Brasil, André Rebouças viveu em um dos períodos mais conturbados do país, fortemente engajado na luta contra a escravidão. As suas propostas de reforma social reiteram o compromisso que sempre norteou o seu pensamento. Na sua proposta abolicionista, havia a preocupação com a integração social do ex-escravo como condição necessária para o progresso brasileiro. A Democracia Rural de Rebouças protagoniza os seus ideais reformistas e centra-se na compreensão de que o monopólio da terra constituía um dos maiores, se não o maior, obstáculo à construção de um capitalismo dinâmico e de uma democracia genuína.

A questão racial me foi extremamente central devido à peculiar trajetória de vida de André Rebouças enquanto intelectual negro em um contexto de escravidão. Através da análise da narrativa de si de Rebouças, pude compreender mais sobre a dimensão do racismo na sociedade em que viveu e na sua própria vida. Embora, de modo geral, tenha sido reticente em relação a esse assunto, abordando-o marginalmente até o ano de 1889, a vivência em África acarretou uma mudança nessa postura, e ele rompeu com o silêncio sobre a sua realidade racial. Essa inflexão no que tange à questão racial na sua vida aparece recorrentemente nas suas correspondências no exílio. Leo Spitzer, no livro Vidas de entremeio (2001), discorre sobre o que ele chama de "embaraço da marginalização": aquela situação limítrofe, "entre dois mundos", na qual os indivíduos em processo de assimilação, como André Rebouças, frequentemente se descobrem, em consequência das "barreiras" erguidas para impedir sua integração social no mundo dos dominadores. Para Spitzer (2001) Rebouças estava imerso em um processo assimilacionista que não garantiu a continuidade de sua aceitação e de sua segurança no mundo dos dominadores. No exílio, quando finalmente se percebe rejeitado e excluído pelo 
racismo, a solidez da sua confiança no assimilacionismo e a profundidade de seu compromisso com ele foram questionados.

Através da referência a uma ancestralidade africana e do reconhecimento de si enquanto homem negro e africano, ele passou a encarar de outra forma a questão racial. Hebe Mattos (2013) levanta a hipótese de que esse momento da vida de Rebouças relaciona-se ao tipo de cultura política a que Paul Gilroy chamou de dupla consciência dos intelectuais negros do Ocidente. Ao aprofundar essa questão, pude acrescentar os escritos de André Rebouças às narrativas do Atlântico Negro. Essa perspectiva lança luz sobre a ambivalência da identificação racial que marcou sua vida e, também, reitera a importância de estudar sobre este importante personagem da história do Brasil. Pesquisar sobre André Rebouças, no contexto de estudos sobre o Atlântico Negro, contribui para recontar parte da história moderna fora da sua perspectiva racista, cujos protagonistas são sempre homens brancos.

Além de oferecer respostas sobre a dimensão racial na vida de Rebouças, as cartas do tempo do exílio são, também, um testemunho dramático de suas desilusões tanto em relação ao Brasil quanto ao "continente mártir²5". Isso porque ele projetou, em África, os seus sonhos frustrados em relação ao Brasil. Mesmo admitindo-se as semelhanças existentes entre a colonização portuguesa na África e no Brasil, essa projeção reflete certa ingenuidade, utopia (JUCÁ, 2001).

A análise do seu pensamento mostra uma postura intelectual surpreendente e, algumas vezes, até contraditória - como, aliás, é observado em outros aspectos de sua vida (JUCÁ, 2001). Por exemplo, era um defensor assíduo da reforma agrária, mas monarquista; intelectual negro que viveu na pele a segregação racial norte-americana, mas apaixonado pela cultura yankee e, no âmbito mais íntimo, era um apaixonado pela ópera; e, no entanto, terminou seus dias sozinho e de maneira trágica na Ilha da Madeira.

Ainda no que tange ao pensamento social de Rebouças, sabe-se que ele teve de lidar com o discurso científico que era produzido pela elite intelectual no Brasil em finais do século dezenove. Ele dialogou com esse pensamento social de cunho racista e, em alguns aspectos, é possível afirmá-lo como "um homem de seu tempo", que reiterou alguns desses discursos. Rebouças, no entanto, era um abolicionista verdadeiramente preocupado com as consequências da abolição para a população escrava. Ou seja, em oposição aos intelectuais que idealizavam o futuro da nação

25 Rebouças, André. Registro de Correspondência, Vol. II, 19 de junho de 1891. Acervo Fundação Joaquim Nabuco. 
sem a presença dos negros, ele não queria a perpetuação do status quo. Eram projetos de nação diferentes, e tentei mostrar o caráter ficcional da ideia de nação, assim como discorrer sobre de que maneira, no Brasil, forjar a identidade nacional tinha como pressuposto a exclusão de vários sujeitos.

Apesar das contradições e de ter sido, em alguns aspectos, um "homem de seu tempo", André Rebouças foi também um precursor das importantes narrativas do Atlântico Negro, o que contribui para pensar a modernidade segundo uma perspectiva marginalizada: a de um homem negro. Finalizando com as palavras do próprio Rebouças:

Cumpre ao africano André ter toda a veemência do sol do continente mártir. Quando eu morrer, dirão: foi o maior inimigo dos fazendeiros - epitáfio que me agrada muito pela novidade porque nunca ninguém o teve no Brasil e, por hora, ainda ninguém quer ter. Mas a herança aí fica e verá que aparecerão logo muitos apóstolos para a Democracia Rural Brasileira. Quanto a mim, desejo apresentar-me ao juiz supremo, dizendo: "trabalhei o quanto pude para extirpar do mundo o monopólio da terra e a escravização dos homens ${ }^{26 ”}$.

\section{REFERÊNCIAS BIBLIOGRÁFICAS}

Acioli, Vera Lúcia Costa. Diários de André Rebouças. Recife: 2010.

Anderson, Benedict. Comunidades Imaginadas: Reflexões sobre a origem e a difusão do nacionalismo. São Paulo: Companhia das Letras, 2008.

Albuquerque, Wlamyra. Uma história do negro no Brasil. Salvador: Centro de Estudos Afro-Orientais; Brasília: Fundação Cultural Palmares, 2006. Disponível em: http:// www.ceao.ufba.br/livrosevideos/pdf/uma\%2ohistoria\%20do\%20negro\%20no\%20 brasil.pdf

Alonso, Ângela. Ideias em movimento: a geração de 1870 na crise do Brasil Império. Tese (Doutorado). Faculdade de Filosofia, Letras e Ciências Humanas, Universidade de São Paulo. São Paulo, 2000.

Alonso, Ângela. Flores, Votos e Balas: o movimento abolicionista brasileiro (1868-88). $1^{\mathrm{a}}$ Edição, São Paulo: Companhia das Letras, 2015.

Borges, Vavy. "Grandezas e misérias da biografia”. In: Pinsky, Carla Bassanezi (org.). Fontes históricas. São Paulo: Contexto, 2008.

26 RebouçAs, André. Registro de Correspondência, Vol. II, 19 de junho de 1891. Acervo Fundação Joaquim Nabuco. 
Carvalho, Maria Alice. O quinto século. André Rebouças e a construção do Brasil. Rio de Janeiro: Iuperj / Revan, 1998.

Costa, Wilma Peres. A atualidade de André Rebouças. Revista Brasileira de Ciências Sociais, v. 14, n. 40, 1999.

Costa, Sergio. Dois Atlânticos: teoria social, anti-racismo, cosmopolitismo. Belo Horizonte: Editora UFMG, 2006.

Del Priori, Mary. Biografia: quando o indivíduo encontra a história. Topoi, v. 10, n. 19, p. 7-16, 2009.

Diário Íntimo do engenheiro Vauthier, 1840-1846. Prefácio e notas de Gilberto Freyre. Rio de Janeiro: Serviço Gráfico do Ministério da Educação e Saúde, 1940.

FERnANDEs, Florestan. "A sociedade escravista no Brasil”. In: Fernandes, Florestan. Circuito Fechado. São Paulo: Hucitec, 1976.

Gilroy, Paul. O Atlântico negro. 2. ed. São Paulo: Editora 34, 2012.

Alencastro, Luiz Felipe; Novaes, Fernando. História da vida privada no Brasil: Império. São Paulo: Companhia das letras, 1997.

JucÁ, Joselice. André Rebouças: reforma \& utopia no contexto do segundo império: quem possui a terra possui o homem. Rio de Janeiro: Odebrecht, 2001.

Mattos, Hebe. André Rebouças e o Pós-abolição: entre a África e o Brasil (18881898). Natal, Rio Grande do Norte, 2013.

Mello, Evaldo Cabral de. “O fim das casas-grandes”. In: Alencastro, Luiz Felipe; Novais, Fernando A. (org.). História da vida privada: Império. São Paulo: Companhia das Letras, 1997, p. 386-473.

Muaze, Mariana. As memórias da Viscondessa: família e poder no Brasil Império. Rio de Janeiro: Jorge Zahar Ed., 2008.

Nabuco, Joaquim. O Abolicionismo. Petrópolis, Rio de Janeiro: Editora Vozes, 2012.

RebouçAs, André. Catálogo de correspondências. 1873-1898. 9 v. (manuscritos originais). Diário, 1863-189o. 25 v. (manuscritos originais).

. Diário e Notas Autobiográficas. Texto escolhido e anotado por Ana Flora e Inácio José Veríssimo. Rio de Janeiro: Editora Ed. José Olympio, 1938.

SANTOS, Gislene. A Invenção do Ser Negro: Um percurso das idéias que naturalizaram a inferioridade dos negros. São Paulo e Rio de Janeiro: Editora da PUC-SUP e Pallas Editora e Distribuidora Ltda, 2005.

Schimidt, Benito Bisso. "História e biografia". In: CARdoso, Ciro Flamarion; VAIFAs, Ronaldo (orgs.). Novos domínios da história. Rio de Janeiro: Elsevier, 2012, p. 187-205.

Schwarcz, Lilia, Pedrosa (org.). Histórias mestiças: antologia de textos. Rio de Janeiro: Cabogó, São Paulo, 2014, p. 291-292. 
Schwarcz, Lilia Mortiz, O Espetáculo das Raças: cientistas, instituições e questão racial no Brasil 1870-193o. São Paulo: Companhia das Letras, 1993.

STEDILE, João Pedro (org.). A questão agrária no brasil: O debate tradicional 150o-196o. 2. ed. São Paulo: Editora Expressão Popular, 2011.

SPITZER, Leo. Vidas de entremeio: assimilação e marginalização na Áustria, no Brasil e na África Ocidental, 1780-1945. Rio de Janeiro: EdUERJ, 2001.

TRINDADE, Alexandro Dantas. André Rebouças: da engenharia civil à engenharia social. Tese (Doutorado em Sociologia) - Instituto de Filosofia e Ciências Humanas, Universidade Estadual de Campinas. Campinas, 2004. 